\title{
THE EFFECT OF LEADERSHIP, CAREER DEVELOPMENT AND COMPENSATION ON WORK SATISFACTION IN THE FINANCIAL MANAGEMENT AGENCY AND REGIONAL ASSETS OF THE PROVINCE OF WEST NUSA TENGGARA, INDONESIA
}

\author{
Yuri Al Amin*, Agusdin, Suparman Lalu \\ Master's Program of Management, Faculty of Economics and Business, \\ University of Mataram, Indonesia \\ *E-mail: yurialamin86@gmail.com
}

\begin{abstract}
This research was motivated by the role of job satisfaction in the outcome of work. Job satisfaction can be influenced by leadership, career development and compensation. The purpose of this study were to analyze the influence of leadership on job satisfaction; analyze the effect of career development to job satisfaction; analyze the effect of compensation on job satisfaction. Data analysis and hypothesis testing is done with the approach of this study Partial Least Square (PLS) using software SmartPLSversi 3.0. Menunjukkah research results that (1) leadership has positive and significant impact on job satisfaction, (2) career Development has a positive and significant impact on job satisfaction, (3) compensation has a positive and significant impact on job satisfaction.
\end{abstract}

\section{KEY WORDS}

Job satisfaction, leadership, careers, compensation.

Human Resources Management (HRM) in a business organization or a public organization certainly has its goals and objectives are to achieve the expected performance, a high level of attendance, turnover as low as possible, and high job satisfaction.

Job Satisfaction (job Satisfaction) as an emotional state that is favorable or unfavorable to which employees view their job. Job satisfaction is very important because it affects absenteeism, labor turnover, morale, complaints, and issues other vital personnel. (Handoko, 2014: 193)

Career development factors influence job satisfaction. Employees who work in an organization will be more motivated to work if leaders pay attention to the career development of his subordinates.

Career development (career development) is a lifelong series of activities that contribute to the exploration, establishment, success, and fulfillment of one's career (Dessler, 2015: 379). Career is a formal approach used by the organization to improve his position through the appropriate qualifications and experience when needed. Formal career development will be critical to maintaining the motivation and commitment of employees (Mondy and Noe, 2005: 237).

Other factors that can increase employee job satisfaction are compensation. Compensation is everything received by the employee / employees as remuneration for their work. (Handoko, 2014: 155). Compensation of employees / employee (employee compensation) includes all forms of payment given to the employee / employee and arising from their employment relationship (Dessler, 2015: 417).

Studies on the relationship of leadership on job satisfaction has been done by Suryadharma et al (2016), with the results that the leadership of significant positive effect on employee satisfaction. While the research Tondok and Andarika (2004), Brahmasari and Suprayitno (2008) as well as research by Pratt (2012) found that leadership significant negative effect on job satisfaction.

Gunawan (2017) conducted a study that showed that career development is significant positive effect on employee job satisfaction. While the research Khotimah (2014), and Hadiwijaya (2016), as well as Mabruroh et al (2017) found that career development is not significant positive effect on job satisfaction. 
Suryadharma et al (2016), carried out with hOutcome studies show that compensation significant positive effect on job satisfaction karyawan.Sedangkan on Pioh research and alum (2016) and Mabruroh et al (2017) showed that compensation significant negative effect on job satisfaction.

Differences may occur research results are expected for an object of research/studies differ, the measurement of the indicator variables and different variables, analytical tools used and the location and the object under study, so as to provide an opportunity for researchers to conduct studies with the same title today. Given that there are a number of studies on the private sector which found that leadership, career development and compensation effect positive/negative significantly to job satisfaction, the researchers wanted to try to reexamine these variables in sectors public.Atas this basis, the researchers wanted to test the variables of leadership, career development and compensation for that job satisfaction conducted research on job satisfaction.

Based on the description of the importance of research on job satisfaction, leadership, career development and compensation and their research found a gap in the relationship between variables. Thus, researchers interested in conducting further research into the public organizations in Finance and Asset Management Agency for the Province of West Nusa Tenggara.

So the hypotheses that can be revealed through this research are:

$\mathrm{H} 1$ : It was alleged that the leadership of significant positive effect on job satisfaction of Finance and Assets Management Agency of the Province of West Nusa Tenggara;

H2: Suspected career development significant positive effect on job satisfaction of Finance and Assets Management Agency of the Province of West Nusa Tenggara;

H3: Suspected compensation significant positive effect on job satisfaction of Finance and Assets Management Agency of the Province of West Nusa Tenggara.

\section{METHODS OF RESEARCH}

This research is associative with the shape of a causal relationship. According Sugiyono (2017: 59) the causal relationship is a relationship that is both cause and effect. So, here are the independent variables (influence) and the dependent variable (affected). This means that the research focuses on the Effect of Leadership, Career Development and Compensation on Job Satisfaction in Finance and Assets Management Agency of the Province of West Nusa Tenggara.

The population in this study is all Civil Servants who work in the Finance and Assets Management Agency of the Province of West Nusa Tenggara number of 124 respondents. The main techniques of data collection in this research are by using a questionnaire / questionnaire technique. Questionnaire technique is a method of data collection using a number of written questions that are used to obtain information from respondents. Questionnaire used was a questionnaire immediately and closed, meaning that the questionnaire given directly to respondents and respondents can choose one of the alternative answers that have been provided. Data collection tools in this study are questionnaires which is a written statement that is used to obtain information from respondents.

A quantitative approach used in this analysis is a model approach Partial Least Square. (Ghozali, 2011:18) states PLS is a factor indeterminacy powerful analytical methods because it does not assume the data must be with a certain scale measurements and small sample size. PLS approach used by the consideration that PLS has an advantage compared with other quantitative approaches.

\section{RESULTS AND DISCUSSION}

To determine the level of significance of the path coefficient, $p$ value generated by running a bootstrapping algorithm must be lower than the level of 0.05 means that the 
hypothesis would be supported if the $p$ value is less than the critical value of 0.05 . The test results can be seen in the level of significance in the image below.

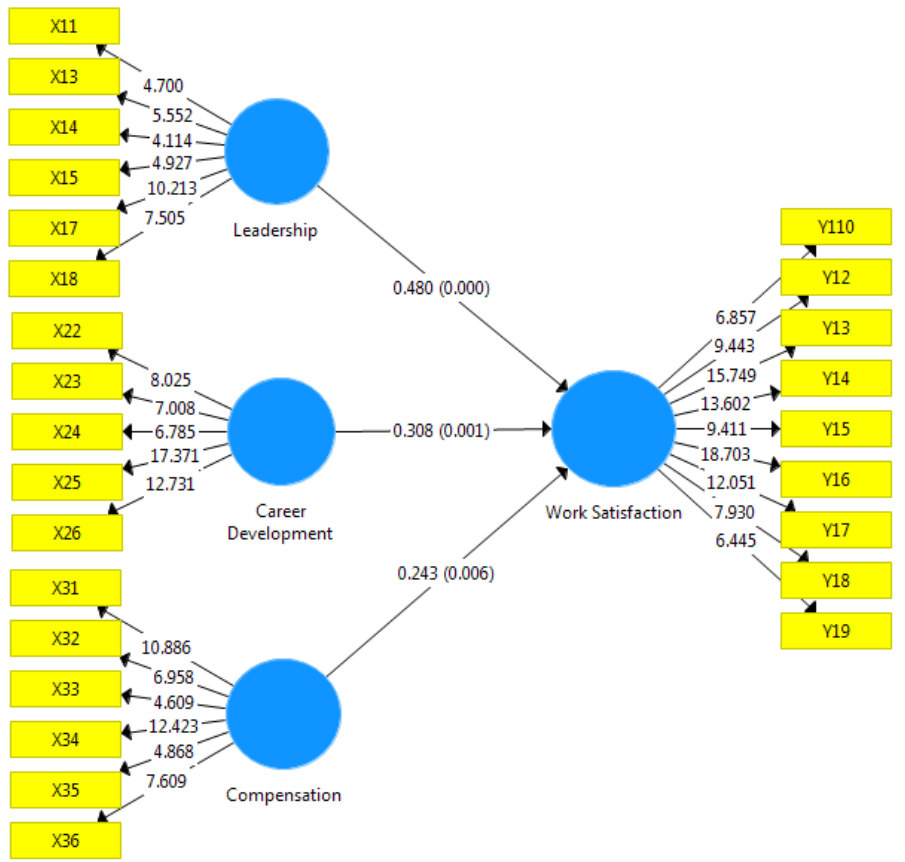

Figure 1 - Test Results bootstrapping In SmartPLS

Based on the above figure can be seen that the leadership has a positive effect of 0.480 on Job Satisfaction in Finance and Asset Management Agency Nusa Tenggara Province Baratdengan significance level of 0.000 , which means a significant, so it can be concluded that the first hypothesis can be accepted. It can be stated that the leadership has a positive and significant impact on job satisfaction. The statement can be interpreted that if the implementation of more effective leadership behavior then certainly employee satisfaction will be more satisfied and vice versa if the less effective leadership behaviors that will decrease job satisfaction (dissatisfied).

Career development have a positive effect amounting to 0,308 on Job Satisfaction in Finance and Asset Management Agency Nusa Tenggara Province Baratdengan significance level of 0.000 , which means a significant, so it can be concluded that the second hypothesis is acceptable. From these results it can be stated that the career development and significant positive effect on job satisfaction. This means that if more and more career development opportunity for employees, employee satisfaction will also be satisfied; otherwise if the employee career development opportunities for the less likely the employee satisfaction decreases/the less satisfied.

Compensation has a positive effect amounting to 0,243 on Job Satisfaction in Finance and Assets Management Agency of the Province of West Nusa Tenggara with a significance level of 0.004 , which means a significant, so it can be concluded that the third hypothesis is accepted. From these results it can be stated that the compensation positive and significant effect on job satisfaction. This means that if the compensation received by employees felt more fair, equitable or appropriate then employee satisfaction will be increased/more satisfied; conversely if the compensation received by the perceived lack of a fair, equitable or less fit then employee satisfaction will decline or the less satisfied.

\section{CONCLUSION AND RECOMMENDATIONS}

Leadership has a positive and significant impact on Job Satisfaction in Finance and Asset Management Agency NTB Provincial. The more effective the behavior of leaders' in his leadership will be followed by a higher level of employee satisfaction at work. Conversely the 
less effective in carrying out its leadership of leader behavior will be followed by the lower level of employee satisfaction at work.

Career development has a positive and significant impact on Job Satisfaction in Finance and Asset Management Agency NTB Provincial. The more definite career development opportunities within the organization, will be followed by a higher level of employee satisfaction at work.

Compensationhas a positive and significant impact on Job Satisfaction in Finance and Asset Management Agency NTB Provincial. The more fair and adequate provision of compensation to every employee, will be followed by a higher level of employee satisfaction toward work and institutions.

Recommendations:

The Chairman of the Finance and Assets Management Agency Nusa Tenggara Province Baratperlu to continue directing subordinates morale through activities undertaken apples every morning as well as in formal meetings and informal. This needs to be done as an effort to improve the morale of the employees so that the objectives of the institution to be more easily achieved.

Finance and Asset Management Agency Nusa Tenggara Province Baratperlu open access to the good cooperation in the academic and private sectors in the realm of human resource development. Through this policy, the direction of development of the human resources possessed becomes more directed to the front.

Empowerment through more active by providing training that is practical and directly related to the work of the employees so that the training conducted become more real to the needs of the employees work. So that the problems qualifying knowledge and skills are still not in accordance with the demands of employee tasks can be resolved.

\section{REFERENCES}

1. Andarika, Rita., (2004), The Relationship Between Perceived Transformational and Transactional Leadership Styles with Job Satisfaction. PSYCHE Vol. 1 No. 1.

2. Brahmasari Ida Ayu and Suprayetno, Agus., (2008) .Pengaruh Work Motivation, Leadership and Organizational Culture on Employee Satisfaction and Impact on Corporate Performance (Case Study at PT. Pei Hai International wiratama Indonesia) .eJournal of Management and Entrepreneurship. Vol.10, NO. 2, September 2008: 124-135.

3. Dessler, G. 2015. Human Resource Management (Translation). Jakarta: Four Salemba.

4. Gunawan, Andri., (2017), Effect of Compensation and Career Development Job Satisfaction Motivation Nurses Who Work At mediated by Bina Kasih Hospital Pekanbaru.E Fekon JOM-Journal Vol. 4 No. 1, February 2017.

5. Hadiwijaya, Hendra., (2016), Effect of Incentives and Job Satisfaction Career Development Through Employee Performance As an intervening variable. National .Seminar Information Technology, Business and Design, PalComTech, 12 May 2016.

6. Handoko, Hani T. (2014). Personnel Management and Human Resources, Issue 2.

7. Khotimah (2014), Effect of Leadership and Career Development And Job Satisfaction on Employee Performance impact. E-Journal of Management Science, 2(2) April 2014.

8. Mabruroh (2017), Effect of Career Development and Work Environment on Employee Satisfaction Dungus Madiun.Vol Pulmonary Hospital. 5 No. 1, October 2017. 86-97.

9. Mondy, R. (2005). Human Resource Management.9th ed. Pearson Prentice Hall. USA.

10. Pioh, Nancy L. (2016), Effect of Compensation and Working Environment Against Job satisfaction and employee performance (Study on civil servants in the District Office Sonder Minahasa District) .e-Journal EMBA Vol.4 No. 838 June 2, 2016, p. 838-848.

11. Primary, Christian Yogi., (2012), Effect of Autocratic Leadership Style on Job Satisfaction. E-JurnalJournal of Social and Industrial Psychology JSIP 1 (2) (2012).

12. Sugiyono, 2017 Business Research Methods, fourth printing, CV Alfabeta, Bandung.

13. Suryadharma (2016), Effect of Leadership and Compensation Committee on Job Satisfaction and Employee Performance (Study at PT. Bpr Sri Artha Sustainable Denpasar) E-Journal of Economics and Business University Udayana 5.2: 335-358. 